\title{
A TEARFUL DIASPORA
}

\section{Preaching religious emotions in the Huguenot Refuge*}

\section{David van der Linden}

RADBOUD UNIVERSITY NIJMEGEN

Huguenot refugees were big weepers. Take the example of Jacques Pineton de Chambrun (1635-1689), a refugee minister from Orange. When royal dragoons entered his town in October 1685 he gave in to fear and converted to Catholicism, like so many Protestants who abjured their faith after Louis XIV revoked the Edict of Nantes and sent troops into the provinces to force Huguenots to join the Church of Rome. Pineton de Chambrun soon came to regret his conversion, however, and in 1686 he fled to Geneva and returned to the Reformed Church. He eventually moved to The Hague, where he published a tear-jerking account of his unfortunate conversion and subsequent repentance, under the revealing title Les larmes de Jacques Pineton de Chambrun. As he explained in the preface,

ever since my unfortunate fall my heart has dissolved because of the sighs from the midst of my bowels, \& I have had no need to make Jeremiah's wish that it should please God that my two eyes change in two vivid sources of tears, because these tears already were on my cheeks day and night, running from my eyes not drop by drop, but as torrents. ${ }^{1}$

Such emotional episodes of confession, repentance, and spiritual rebirth were not exceptional within the Huguenot diaspora. In exile centres across Europe, refugees time and again recounted the horrors of the persecutions in France and pleaded forgiveness for their temporary lapse into Catholicism — a ritual known as reconnaissance. French exile churches devised clear procedures for such born-again

* I am grateful to the Scaliger Institute at Leiden University for funding vital research in the collections of the Bibliothèque Wallonne, held in the Leiden University Library. 
Huguenots, who had to beg God's forgiveness in front of the entire community and sign a confession before they were welcomed back into the Protestant fold. ${ }^{2}$ In February 1686, for instance, Pierre Aislé, a seventy-two-year-old refugee from Sedan, repented of his conversion in the French church of Nijmegen. The consistory acts report that during a highly emotional service he was encouraged 'to acknowledge his sin with bitter tears and to beg God for pardon, which he did facing the Church, and this wonderfully edified our community'. ${ }^{3}$ Pineton de Chambrun likewise recalled that upon arrival in Geneva he had appeared before the church elders, 'showing them the sentiments of my heart, and by my tears gave them so many marks of my repentance, that they could not help mixing theirs with mine'.

As this chapter will argue, feelings of loss, abandonment, and contrition were crucial to the Huguenot exile experience. On the one hand weeping in church and recounting dramatic stories of suffering and rebirth conferred on refugees a sense of pride and election. Precisely because they had abandoned hearth and home for the sake of religion, Huguenot exiles were able to fashion themselves as devout believers and to turn their traumatic escape from France into a glorious exodus ordained by God. Yet the emotional experience of exile was far more complicated than the biblical trope of fall, flight, and repentance might suggest. The many tales of courage and rebirth that permeate the Huguenot diaspora in fact mask a deep-seated unease among the refugees, who were also grappling with feelings of abandonment and anxiety. Why, for example, had God allowed the destruction of his churches in France? If the Huguenots were God's chosen people, why did he make them suffer persecution and force them into exile? And when would they be able to return home?

To analyse these emotional pressures, this chapter explores the sermons preached by Huguenot ministers in exile. Although early modern sermons have often been regarded as a rather dry and tedious genre, helpful at best to understand the consolidation of church doctrines in the Protestant and Catholic Reformations, in recent years historians have emphasized the many political, cultural, and literary dimensions of preaching, in particular in the British Isles. ${ }^{5}$ Research on the emotionality of the early modern sermon is still sparse, but existing studies suggest that preachers indeed used the pulpit to mould the religious feelings of their flock. Margo Todd, for example, has found that Reformed ministers in Scotland regularly mixed straightforward exegesis with an evocative preaching style, instilling the fear of divine wrath in the hearts of believers, just as Arnold Hunt has shown that Puritan ministers did not shy away from stirring up the emotions to obtain a sincere repentance. ${ }^{6}$ Susan Karant-Nunn has demonstrated that in post-Reformation Germany, Catholic, Lutheran, and Calvinist preachers relied on sermons to shape the feelings of their audiences—what she calls 'emotional scripts' 7 Contributors to a special issue of English Studies, 'Rhetoric, Emotion and the Early Modern English Sermon', likewise stressed that early modern sermons were not simply a learned form of biblical exegesis, but also served to change the hearts and minds of believers, and to provoke an emotional response from audiences. ${ }^{8}$ 
This chapter adopts a similar approach, analysing the sermons preached by exiled Huguenot ministers to uncover the emotional experience of exile. It argues that sermons were a powerful medium to counter the worries of Huguenot refugees, to channel their emotions, and to offer a message of hope and comfort. Rather than statements of doctrine, sermons facilitated an emotional dialogue between a preacher and his audience. As such, they were crucial for the construction of what Barbara Rosenwein has called 'emotional communities': groups of people who value and devalue the same emotional norms. ${ }^{9}$ Rosenwein's concept is particularly useful for understanding religious emotions and the emergence of diasporic identities in the early modern period. Through their sermons, Huguenot ministers were able to address the many anxieties of the refugees and bind them together as a suffering yet strongminded community, while in printed form they also reached refugees in other exile centres, as well as Protestants who had stayed behind in France. Preaching thus allowed ministers to re-constitute the dispersed Huguenots as an emotional community across borders.

Because it falls outside the scope of a single chapter to offer a comprehensive overview of Huguenot exile sermons, this essay will focus on the Dutch Republic, one of the major destinations for Huguenot refugees and ministers and by far the most important centre for the production of printed exile sermons. The chapter has been divided into four parts. The first section explores the Calvinist tradition of religious emotions and analyses how Huguenot ministers in the post-Reformation period relied on emotional arguments to comfort the refugees. The second part focuses on the recurrent theme of penitential tears as an emotional strategy to touch the hearts and minds of those Protestants who had not gone into exile, but had converted to Catholicism and remained in France. The two last sections will address ministers' emotional preaching styles and audience responses, asking to what extent refugee ministers succeeded in forging an emotional community among the dispersed Huguenots.

\section{The emotions of the exiles}

Calvinism has often been viewed as a stern faith averse to emotions, but in truth it was deeply marked by the medieval tradition of moving audiences to repentance through vivid preaching. From the fifteenth century onwards, preachers had begun to heighten the emotional tone and style of their sermons: they increasingly focused on the suffering of Christ in all its gory details, hoping that audiences would identify with his agony, understand that he had willingly endured these pains to atone for mankind's sins, and as a result be moved to repentance. The Tridentine reforms of the sixteenth century only intensified the emotionality of Catholic sermons, as new monastic orders and reform-minded prelates such as the Milanese archbishop Carlo Borromeo (1538-1584) stressed the importance of preaching to inspire piety and penance. What was initially an Easter time phenomenon-emotional sermons to exhort audiences to an imitatio Christi - thus became a continuous feature of Catholic preaching. ${ }^{10}$ 
Although Protestant reformers differed in their appreciation of religious feelings, it is important to note that they continued to rely on emotional strategies in their sermons. Luther and Calvin only sought to dampen the outward demonstration of religious fervour, as they argued that reliving Christ's suffering and doing penance could not in itself merit God's forgiveness, which was a gift freely conferred upon Christians. Luther believed that by focussing on the agony of Christ, believers missed a crucial point: God's compassion in offering up his only son to atone for the sins of man. Yet Lutheran preachers never eliminated the emotions from their sermons; rather than preach on the agonies of Christ, they stressed God's love, mercy, and comfort. ${ }^{11}$

Calvin also condemned the emotionality of the old Church: instead of making a show of their emotions, he argued that believers should quietly contemplate their sins. Calvin nonetheless acknowledged the power of religious feelings, as he stressed that Protestants are stirred by the Holy Spirit, who moves them to accept God's word, and to recognize their mistakes. ${ }^{12}$ Preaching on the story of the apostle Peter, who had wept bitterly after renouncing Christ, Calvin noted that Peter was overwrought with grief, which should inspire believers to follow his example. Still, the apostle only cried when he was alone: 'He clearly shows that he's touched by his mistake, because he doesn't seek witnesses among men to make a show of his repentance, but weeps alone before God' Here was a powerful lesson for Protestants, according to Calvin: 'If we cry only before men, we show our hypocrisy; but if someone privately engages in prayer, \& examines his mistakes \& sins, if he's thus touched by anguish, that's a sign that he's not feigning'. ${ }^{13}$ Far from eliminating religious sentiments, then, Calvin believed they played a key role in moving believers to acknowledge their sins and convert themselves to a more pious life.

To understand how Huguenot refugee ministers applied Calvin's teachings in their day-to-day preaching, we have a large corpus of exile sermons at our disposal. The vast majority were printed in the Dutch Republic: between 1685 and 1700 , over fifty titles and as many as 300 individual sermons appeared on the market, most printed as collections. This output was largely the result of the massive influx of Huguenot ministers to the United Provinces in the wake of the Revocation: out of the 680 ministers who left France, at least 405 went to the Dutch Republic. They were drawn in particular by the prospect of continuing their clerical career in one of the many French-speaking communities, known as Walloon churches, which had been established by Protestant refugees from the Southern Netherlands in the late sixteenth century. Freed from the constraints of Catholic censorship in France, they proved remarkably prolific in publishing their sermons. ${ }^{14}$

Like any early modern sermon, the main objective of the Huguenot exile sermon was to confirm refugees in their faith and to explain to them the mysteries of the Christian religion. Yet for refugee ministers the point of preaching on Calvinist doctrine was not simply to instruct believers. Once in exile, sermons gained additional meaning, as ministers sought to address the worries of the 
Huguenots, and to offer them a message of consolation and hope. For this, theology provided a useful starting point: ministers found that they could use Calvin's teachings to explain why the Revocation had happened and to reassure the refugees that as God's chosen people they would eventually be able to return to France. Emotional strategies thus became a key feature of Huguenot preaching in exile.

The most appropriate doctrine on which ministers relied to comfort the refugees was that of providence, which taught Huguenots that God's hand was behind every event on earth. As Calvin had explained in his Institutes of the Christian Religion, philosophers may argue that sheer chance is responsible for unfolding events, but true believers know that it is God who 'sustains, nourishes, and cares for everything he has made'. ${ }^{15}$ Refugee ministers argued that because events on earth were the result of divine interference, it stood to reason that the Revocation was also a product of God's omnipotence: he had unleashed the Revocation to punish the Huguenots for their sins. In their sermons, ministers indeed often lamented the state of their communities before 1685, condemning the vices that had corrupted them. It was only fair that God had punished the Huguenots by destroying their churches, they argued-the Revocation was nothing less than a wake-up call to better their lives. In 1686, the consistory of the Walloon church in Delft even ordered its ministers to preach on God's anger and the necessity to repent, noting that 'all pious and Christian duties shall be employed to calm God's ire, which is so strongly inflamed against His Church'. Each minister was told to exhort the audience to humiliation, and 'to write his sermon particularly to this end'. ${ }^{16}$

We know that refugee ministers elsewhere in the Dutch Republic also preached on the sins of their communities to explain the persecutions. In a sermon held in 1685 in the Walloon church of The Hague, Jean Claude (1619-1687), the famous Huguenot minister from Paris, asked the question that was on everyone's mind:

How come, then, that it seems as if He [God] has let out over all of us the fire of his indignation, without sparing his sanctuaries, nor his assemblies, nor the shepherds, nor his flocks, nor the ministry of his Gospel, nor even the profession of his truth? ${ }^{17}$

The answer was simple enough: afflictions on earth were the result of God's providence. Claude told the refugees to look beyond Catholic persecution, which, he argued, was merely a 'secondary cause' of the Lord's providence, an 'impure channel' through which he sent his afflictions; the true root of all adversity was their own misconduct. ${ }^{18}$

Yet ministers were well aware that explaining the Revocation as a divine punishment was not much of a consolation to the refugees. Fortunately, the doctrine of providence also held out the promise of an end to exile. When Calvin had discussed providence in his Institutes, he also noted that 'in times of 
adversity, believers comfort themselves with the solace that they suffer nothing except by God's ordinance and command, for they are under His hand' ${ }^{9}$ Although it appeared that God had abandoned them, suffering from persecution and exile thus marked the Huguenots out as God's chosen people. It is not surprising that ministers eagerly seized upon this argument to comfort the refugees: they maintained that despite the destruction of their communities in France, God had still destined a happy few to be saved. He had deliberately put them to the test by unleashing Catholic persecution, knowing that only the devout would persevere in their faith, while the fainthearted would convert to Catholicism. The refugees who had fled into exile were God's chosen people, a community of refugee-elect who could one day replant the standard of Protestantism in France. Persecution and exile, then, could be interpreted as a sign that God's ultimate aim was to sift the true believers from the fainthearted. God's anger was at the same time a sign of his boundless love.

This point was made most persuasively by Jacques Abbadie (1656-1727), a Huguenot minister from the Béarn who preached at the French church of Berlin. When in November 1685 the Elector of Brandenburg sent him on a mission to The Hague to recruit enterprising refugees for his lands, Abbadie was invited to give a series of sermons in the local Walloon church, which were then published in $1686 .{ }^{20}$ In one of them, aptly entitled Le feu des afflictions, Abbadie argued that suffering served a clear purpose. In times of adversity, believers are forced to show their true colours, either as sincere Christians, or as hypocrites who cannot bear to sacrifice the comforts of their earthly life to follow Christ. As Abbadie put it, 'afflictions are a test, and this test produces patience, and patience creates hope'. ${ }^{21} \mathrm{He}$ clearly interpreted the tribulations of the refugees as a sign that they were still God's chosen people.

If the faithful suffer persecution, $\&$ if they are exposed to all the furies of this world \& its rulers, we should not be surprised, because Jesus Christ teaches us that all those who wish to live a pious life, will suffer persecution. $^{22}$

Suffering, in other words, was part and parcel of the refugees' condition humaine, marking them out as a faithful community that enjoyed God's benevolence. It also proved a comforting thought because it kept alive hopes for the future restoration of the Reformed Church in France. Refugee ministers reasoned that because the refugees were God's chosen people preserved in exile, he surely meant for them to return home and restore the Protestant communities in France. Jean Claude, for example, referring to the many refugees among his audience, rejoiced that the Lord 'had still left some grapes, as seeds, and elected residue of his grace'. ${ }^{23}$ Abel Rotolp de la Devèze (d. 1709), a minister from Castres who had fled to The Hague, used a similar metaphor. In a sermon preached in May 1687, he presented the refugees with the troubling image of a rotten tree cut down by the Lord and thrown into the fire-yet he consoled 
them by explaining that 'God will by His grace secretly preserve some roots from the remains of this tree, which He will bless, \& which will one day sprout from the bosom of the earth'. ${ }^{24}$ Jacques Abbadie would repeat this argument after he had moved from Berlin to London and began preaching at the French church of the Savoy in $1692 .^{25}$ He told the refugees not to lose courage at the duration of their exile and the slim chances of seeing the Reformed Church in France restored. The destruction of their churches was only physical, he argued, not spiritual, because in exile the refugees kept alive the true faith:

The Church is a spiritual edifice, built by the mercy of God, an indestructible building, even when exposed to the blows of a heavy storm. The winds of God that rattle the vanities of humankind may remove its external ornaments \& ravage the outside, but they cannot destroy the foundation that is Jesus Christ, nor pierce the living stones that compose it, which are our hearts. ${ }^{26}$

\section{Penitential tears and shame}

Huguenot ministers not only sought to comfort the Huguenots in exile. Once their sermons had made it into print they could reach refugees across the diaspora, and even connect with those Protestants who had stayed in France-scathingly called nouveaux convertis (new converts) by the French authorities - and who were forced to practice their faith in secret. The emotional community of dispersed Huguenots that refugee ministers sought to recreate through their sermons thus stretched beyond the boundaries of local exile churches and the states that welcomed them. Indeed, Barbara Rosenwein has argued that emotional communities are significantly strengthened and expanded through the circulation of emotional norms in manuscript and print, allowing people across great distances to become part of the same imagined community. $^{27}$ The Huguenot diaspora was precisely that: a dispersed group whose members sought to maintain the bonds of faith and community after persecution had scattered them across the continent.

Scholars of the Huguenot diaspora have long recognized that refugee ministers used Dutch presses to reach out to their former brethren, but they have only situated this point of contact in the many pastoral letters that ministers wrote to convince Protestants in France to go into exile. It is striking, however, that the Huguenot sermons published in the Dutch Republic carried precisely the same message as these pastoral letters. Both types of spiritual literature firmly denounced the practice of Nicodemism-the hiding of one's faith behind a façade of conformity-and called upon Huguenots to go into exile. ${ }^{28} \mathrm{We}$ know that printed exile sermons circulated widely in France, as royal authorities regularly arrested nouveaux convertis in possession of sermons that had been smuggled into the kingdom. ${ }^{29}$ The prefaces to sermon collections printed in the Dutch 
Republic also reveal the wish of refugee ministers to connect with Protestants in the homeland. For example, when in 1690 Abel Rotolp de la Devèze had twelve of his sermons printed in Utrecht, he explained that his aim was to 'contribute to the consolation of those who are dispersed in places where they rarely hear French preachers, and even more to the salvation of so many Faithful who are absolutely deprived of this happiness in their Fatherland'. ${ }^{30}$

The ministers' call to repentance took on an entirely different meaning within a French context: they hoped to shame the nouveaux convertis into exile, telling them to ask God's forgiveness for betraying their faith. The printed sermons of Jean Guillebert (d.1691), a Normandy refugee minister in the Walloon church of Haarlem, are a case in point. ${ }^{31}$ Guillebert explicitly directed his sermons to 'our brothers who have been forced to abandon the profession of the Gospel' and condemned their abjuration in the face of persecution. Guillebert nonetheless assured them that God would prove merciful, provided they would repent and go into exile. In a sermon ominously entitled Le malheur des apostats, he reminded the nouveaux convertis that they had once been zealous Christians-and that now the time had come to repent and reconnect with their Protestant self. 'Humiliate yourselves profoundly in the presence of the Lord, whom you have so deeply offended; moan and weep incessantly when you remember your weakness', he wrote. ${ }^{32}$

As the example of Guillebert's preaching demonstrates, refugee ministers associated repentance with profound religious emotions. Although feeling shame about one's sins and a change of heart were key to a genuine repentance, it also required weeping. Jacques Bernard (1658-1718), a refugee minister from Dauphiné who preached in the Walloon church of Leiden, neatly summarized these notions in his Traité de la repentance tardive (1712). Having defined repentance as 'a complete return of a sinful man to his God, resulting from love, duty, hope, \& fear', he then cited noteworthy sinners from the Bible who had marked their remorse with tears, such as the apostle Peter and King David. ${ }^{33}$ Yet Bernard warned that crying was not a substitute for inner contemplation. Like Calvin, he argued that repentance began with an inner change of heart, and disapproved of gratuitous weeping: 'People think that repentance is simply a displeasure to have offended God, accompanied with some sighs, tears, and promises to their minister, without any real change taking place in their heart, nor in their feelings' ${ }^{34}$ Weeping was merely an accompaniment to repentance, an outward demonstration of one's profound religious turmoil and shame.

The story ministers cited time and again to explain the necessity of repentance and the proper emotional norms that went with it was that of the apostle Peter, who had thrice renounced Christ in the house of the Jewish high priest Caiaphas. When the cock crowed as foretold by Jesus, however, Peter had realized his mistake and left the house weeping bitterly (see Figure 3.1). As we have seen, Calvin already discussed this story to explain the need for an inner reformation, but the theme regularly cropped up again in seventeenth-century sermons. In 1658 for instance, the prominent Huguenot minister Pierre Du Bosc (1623-1692) devoted 
an entire sermon to Peter's tears, telling his audience to weep over their sins and repent just as the apostle had done. In a brief aside, he also encouraged a handful of Protestants who had gone over to the Church of Rome to reconsider their conversion, an argument that foreshadowed a comparison frequently made by Huguenot ministers in the post-Revocation period. ${ }^{35}$

The story of Peter was indeed easily adapted after 1685, when refugee ministers argued that the apostle's fall and subsequent repentance were sure signs that God would have mercy on the nouveaux convertis, if only they would see the error of their abjuration and leave France. In a sermon published in 1693, Samuel de Brais

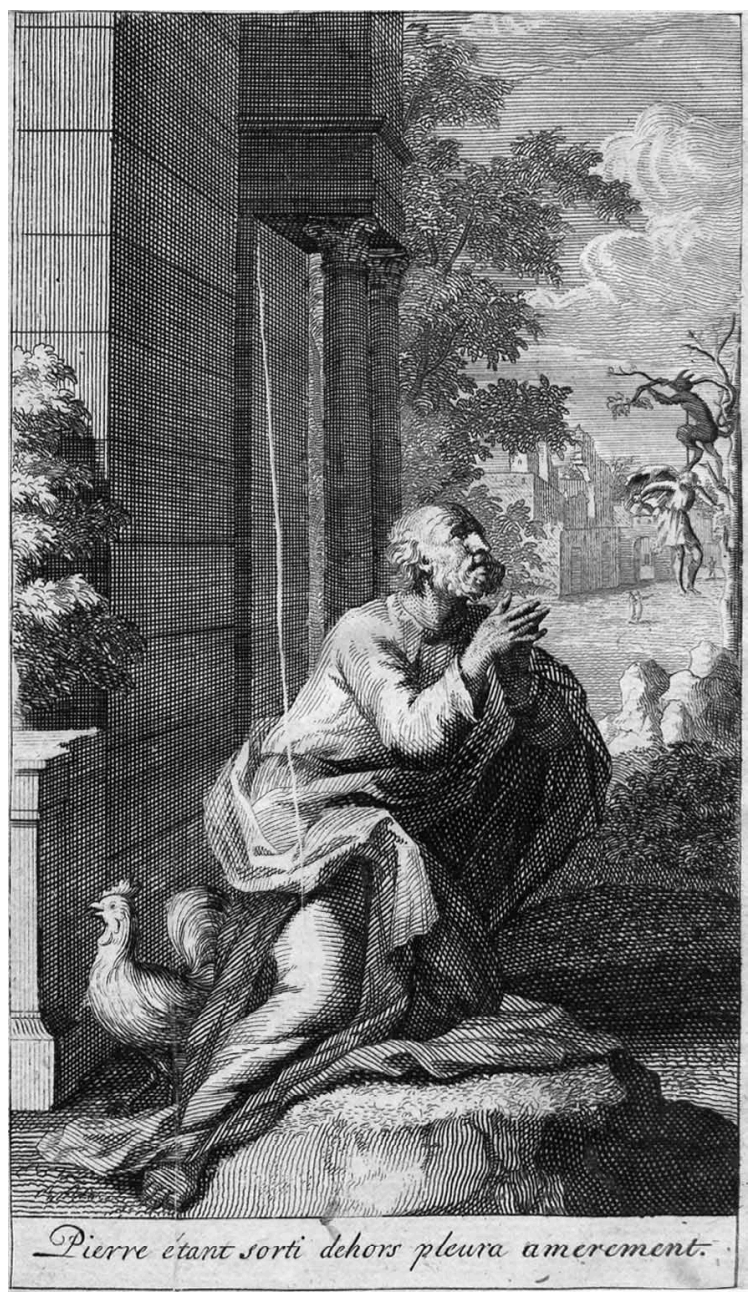

FIGURE 3.1 The apostle Peter weeps bitterly after denouncing Christ, engraving, in Jacques Bernard, Traité de la repentance tardive (Rudolf \& Gerard Wetstein: Amsterdam, 1712), frontispiece. Leiden University Library, BIBWAL K 49. 
(1642-1725), a refugee minister from Normandy, explicitly urged lapsed Protestants to follow in Peter's footsteps by making sincere amends for their abjuration and leaving France. 'Peter's departure from the court of Caiaphas shows us that it is not sufficient for us to genuinely repent, to recognize the sins \& the errors that we had the misfortune to get involved in', he preached. The apostle's departure demonstrated 'that we must promptly leave to follow the rules of a godlier \& more Christian life, ${ }^{36}$ Jean Guillebert preached a similar message of urgency and optimism. Although in his sermons he harshly condemned the widespread apostasy in France, he still nourished hopes that the nouveaux convertis would follow Peter's example and go into exile. Guillebert reminded them that when Peter had 'made amends for his mistake with all those bitter tears that he shed so abundantly, the Lord, touched by compassion, showed him new marks of His tenderness, \& solemnly re-established him in his office of Apostle'. ${ }^{37}$ French Protestants could thus still count on God's grace, provided they were overtaken by remorse, wept bitterly, and fled into exile.

\section{Emotional preaching styles}

Reading exile sermons for their emotional messages offers useful evidence of how Huguenot ministers hoped to convince Protestants that exile was worthwhile, but it tells us very little about their level of success. This section and the next therefore move beyond the message from the pulpit to consider the emotional styles of preaching and the responses of Huguenot audiences, both in exile and in France. Peter and Carol Stearns have termed this approach 'emotionology': the study of the standards a community maintains towards emotions and their appropriate expression. ${ }^{38}$ Exploring how refugee ministers communicated religious emotions is indeed a useful approach for understanding the impact of preaching, since ministers were well aware that to get their message across they had to forge an emotional bond with their audience, not in the least because the refugees were questioning the wisdom of going into exile. Addressing such anxieties required not only a sound knowledge of theology, but also emotional skills.

Huguenot ministers disagreed, however, on what should be the proper emotional style for a sermon. Schooled in the ancient oratorical tradition, they had learnt to appeal not only to the mind, but also to the feelings of their audience. Aristotle for instance believed that cultivating the emotions could reinforce virtuous behaviour, while Cicero and Quintilian advised orators to combine reason and emotion in their speeches. ${ }^{39}$ The homiletical handbooks that appeared in France during the seventeenth century also stressed the importance of emotional strategies. The most influential of these treatises was written by Michel le Faucheur (1585-1657), a Huguenot minister from Paris. In his Traité de l'action de l'orateur he complained that many preachers stood in their pulpit like pillars of salt, reciting their sermons in monotonous voices that inevitably lulled their flock to sleep. Although Le Faucheur conceded that invention, arrangement, 
and eloquence were crucial to composing a sermon, he warned his readers that 'when it comes to pronouncing it in public, \& to effectively touch the minds of all those who listen, they will remain like dead \& without effect if the fourth element [delivery] doesn't invigorate them'. ${ }^{40}$ Le Faucheur thus devoted most of his treatise to practical suggestions on how to vary one's voice and body language.

Yet Huguenot ministers did not necessarily take his advice to heart. Their objections were neatly summed up by Jean Claude, who rejected what he called 'enthusiastic' preaching. In his posthumously published Traité de la composition d'un sermon (1688), he instead advocated a plain style as the best way to deliver a sermon. Rhetorical excesses in voice and gesture would only distract listeners from God's Word, which did not need any human embellishment. ${ }^{41}$ Claude's reservations were echoed by Jacques Colas de la Treille (c.1665-1724), who served as a Huguenot chaplain during the Nine Years' War. He tartly observed that highly emotional sermons may 'bring tears to the eyes of listeners, but they won't be able to explain to themselves why they are crying. ${ }^{42}$ Making an impression on believers was one thing, trying to actually have them understand God's word quite another. Jacques Bernard shared these concerns. Before he was called to the Walloon church of Leiden in 1705, he had scraped together a living as a journalist and tutor in mathematics, philosophy, and homiletics. ${ }^{43}$ As is clear from the surviving lecture notes made by one of his students, Bernard strongly condemned 'false eloquence that always seeks to touch [émouvoir], and turn everything into oratory'. Genuine eloquence, he argued, 'consists of choosing beautiful \& useful topics, \& treating them in a manner that may inculcate in the hearts of listeners the things they're being told'. ${ }^{4}$

This preference for plain preaching had much to do with Calvinist theology, which held that sermons were merely a conduit for the Gospel and could not in themselves convert sinners to repent. It was only through the workings of the Holy Spirit, who opens up the heart and mind, and because of people's own desire to hear God's Word, that sinners are able to receive his grace. Emotional discourse or expressive gestures, in other words, merely touched believers superficially-for a genuine change of heart they were completely useless. Pierre $\mathrm{Du}$ Bosc aptly compared preaching to Christ knocking on the door: ministers may announce the Gospel, but only if people allow him to enter can the message from the pulpit become effective. ${ }^{45}$ In his Traité de la repentance tardive, Jacques Bernard offered up a similar analogy. Sermons, he argued, are like rays of sunshine trying to penetrate a closed chamber: only when the Holy Spirit opens the shutters can the Gospel illuminate the soul. ${ }^{46}$

Emotional preaching also reminded refugee ministers of the missionary priests in France, who had toured the provinces in an attempt to convert Protestants to Catholicism. In the wake of the Council of Trent, new missionary orders had been established to regain territory and souls lost to the Church of Rome, 
including those in France. In the Poitou, for instance, a region densely populated by Protestants, Capuchin friars staged elaborate processions and outdoor masses, convinced as they were that an assault on the senses would provoke an emotional response from Huguenot audiences and win them over to Catholicism. Capuchin missionaries thus delivered their sermons as if they were theatre pieces: services were staged in a public square to accommodate a large audience, and preachers spoke with such empathy that people were reported to be weeping and confessing their sins in public. ${ }^{47}$

Evidence on the actual preaching styles of Huguenot refugee ministers is scarce. The best-documented case is that of Jean Claude's son Isaac (1653-1695), who preached in the Walloon church of The Hague. ${ }^{48}$ Isaac's $^{\prime}$ preaching seems to have been a mix of dry exegesis and vivid delivery. His manuscript sermons reveal that he preferred the point-by-point analysis of biblical passages, which was common for Huguenot sermons, but eyewitness accounts also testify to Isaac's capacities as an orator. According to Jean Rou (1638-1711), a refugee lawyer who had become a translator for the StatesGeneral, Isaac possessed 'a clear pronunciation, natural gestures, a pure diction, as well as grand and noble expressions'. ${ }^{49}$ Apparently, Isaac did pay close attention to how he delivered his sermons. In a sermon held in August 1685, Isaac also reflected on the need for a persuasive preaching style. The faithful, he said, 'mostly imitate, and examples thus make a strong impression upon them. If in their eyes we appear to be exceedingly persuaded of what we announce to them, we persuade them as well'. 50

\section{Audience responses}

The question we are left with, finally, is how effective the preaching of refugee Huguenot ministers really was. Did they succeed in alleviating the sorrows of the Huguenots, and were they able to convince them that exile was a necessary sacrifice? It is difficult to generalize for want of sources, but individual cases do help us understand how audiences responded to exile sermons. What is most striking is that the appreciation for exile sermons varied across the Huguenot community, particularly between those Protestants who had fled and those who had stayed behind in France. This is perhaps not surprising, as Barbara Rosenwein has already pointed out that emotional communities are seldom monolithic, but consist of overlapping subsets. ${ }^{51}$

Surviving evidence from the Dutch Republic suggests that ministers indeed touched the refugees and were able to comfort them in their woeful exile. The most astute observer of refugee preaching was Pieter Teding van Berkhout (1643-1713), a burgomaster from Delft who kept a diary for much of his adult life, in which he also charted the responses of Huguenot refugees to sermons given in the various Walloon churches of Holland. ${ }^{52}$ He noted that ministers often emphatically applied the scriptures to the situation of the exiled Huguenots. In February 1688, for example he went to the Walloon 
church of Rotterdam to hear a sermon by Antoine Le Page (1645-1701), a minister from Dieppe. The refugees were greatly moved by Le Page's sermon, because he sympathized with their difficult life in exile and tried to alleviate their sorrows. Echoing the familiar argument we have seen in other Huguenot sermons, Le Page preached that it was precisely through persecution that the Lord sifted the devout from the insincere. He also sympathized with the refugees who had abandoned their homes and property, which, Van Berkhout noted, caused the refugees 'to melt away in tears'. Yet Le Page immediately offered comfort, telling them 'that they would miss their lost and fleeting possessions but for a short time, and that their affliction could not be great, since the building of God would shortly be finished'. ${ }^{3}$ Le Page's message that the Bible promised the refugees an end to exile and the glorious restoration of the Reformed Church in France was all his audience needed to hear and explains why emotional strategies could be extremely successful in comforting the refugees.

Protestants in France, however, responded very differently to the exile sermons that reached them in print. As we have seen, refugee sermons were packed with praise for the refugees, but they also condemned the nouveaux convertis for their religious weakness, which was hardly a comforting message for Protestants who had stayed behind. After all, leaving France was not a decision most people took overnight: whereas Louis XIV had allowed ministers a safe passage into exile, all other Protestants were forbidden to leave the kingdom on pain of imprisonment or serving the rest of their lives on the galleys. Many Huguenots also felt that the departure of virtually all their ministers into exile had robbed them of the clerical leadership that was crucial for the survival of their faith. As a result, self-appointed preachers without formal clerical training, known as prédicants, soon began to tour the French kingdom to offer improvised services. Most famous among these men was Claude Brousson (1647-1698), a lawyer from Toulouse who had fled to Holland but in 1689 returned to France to become a lay preacher in the Cévennes, where his sermons attracted huge crowds. ${ }^{54}$ Already in 1688, he had accused the refugee ministers of cowardice, arguing that in times of crisis the duty to preach outweighed the dangers of persecution. ${ }^{55}$ In a private letter sent to a refugee minister in The Hague in 1698, he again stressed the need to offer comfort to the nouveaux convertis, rather than accusations. 'God, who is infinitely wiser than us, has sent me here in this time of distress, to comfort and strengthen his children', he wrote, adding that 'never before were our poor people more in need of consolation. May God regard them with compassion and soon put an end to their misery'. ${ }^{56}$ The emotional strategy of shaming the nouveaux convertis thus seems to have backfired. Rather than calls to repentance, Protestants in France needed the same comforting message as the refugees in exile: that despite their suffering, God still regarded them as his chosen people. 


\section{Conclusion}

Exile sermons are a unique source to analyse the emotional pressures and coping strategies of early modern refugees, such as the Huguenots who fled France after 1685. Exiled ministers in the Dutch Republic consciously used their pulpits and pens not only to explain Calvinist doctrine; they sought above all to address the anxieties of the refugees, who had some pressing questions to ask. Why, for instance, did God punish the Huguenots rather than their enemies? Why should exile be preferable to maintaining one's faith in France? And would the Reformed churches ever be restored, allowing them to return home? Refugee ministers responded to these worries by telling the refugees that exile was part of God's master plan to save the Protestants who had been courageous enough to flee. Audience responses suggest that the most popular refugee ministers were indeed those who were not afraid to voice the questions that were on everyone's mind and who relied on vivid delivery to touch the hearts and minds of their audiences. Reading sermons for their emotional messages thus highlights the complex and unsettling experience of exile, rather than the heroic stories told by the refugees.

An analysis of Huguenot exile preaching also shows that the Protestant Reformation did not entirely do away with a conscious focus on emotions as critical to the rhetorical strategies of preaching. To be sure, Calvinists habitually accused the Church of Rome of its predilection for the outward senses and the passions. From their perspective, the Mass had become an emotional show that had little to do with sincere repentance. Yet this dichotomy between Protestant logocentrism and Catholic sensuality was less absolute in practice than it was in theory. Homiletical treatises and audience responses to Huguenot refugee sermons indicate that emotions retained their importance in Protestant services. Just like their Catholic counterparts, Huguenot ministers believed that religious emotions were crucial in moving believers to repentance. The difference was in the detail: when refugee ministers told the familiar story of Peter's betrayal and stressed the need for penitential tears, they were at pains to explain that genuine contrition began with inner contemplation and opening up of one's heart to the Holy Spirit. Yet leaving aside theological subtleties, refugee ministers quickly understood that the uncertainties of exile required an emotional response; they had to forge a bond with their audiences-both in exile and in France-in order to create an emotional community that would serve to bring together the Huguenots dispersed across Europe.

\section{Notes}

1 Jacques Pineton de Chambrun, Les larmes de Jacques Pineton de Chambrun, Pasteur de la Maison de Son Altesse Serenissime, de l'Eglise d'Orange, \& Professeur en Theologie (The Hague, 1687), 2. Unless otherwise noted, all translations are my own. 
2 David van der Linden, Experiencing Exile: Huguenot Refugees in the Dutch Republic, 1680-1700 (Farnham: Ashgate, 2015), 17-19.

3 Consistory Minutes Walloon Church Nijmegen, 21 February 1686, Archives of the Walloon Church 3, Regionaal Archief, Nijmegen.

4 Pineton de Chambrun, Les larmes de Jacques Pineton de Chambrun, 172.

5 A useful overview of sermon studies in the British Isles is provided in Peter McCullough, Hugh Adlington, and Emma Rhatigan, eds, The Oxford Handbook of the Early Modern Sermon (Oxford: Oxford University Press, 2011).

6 Margo Todd, The Culture of Protestantism in Early Modern Scotland (New Haven: Yale University Press, 2002), 50-55; Arnold Hunt, The Art of Hearing: English Preachers and Their Audiences, 1590-1640 (Cambridge: Cambridge University Press, 2010), 81-94.

7 Susan Karant-Nunn, The Reformation of Feeling: Shaping the Religious Emotions in Early Modern Germany (Oxford: Oxford University Press, 2010).

8 In particular the essays by Mary Morrissey, "Exhortation and Sympathy in the Paul's Cross Jeremiads," English Studies 98, no.7 (2017): 661-74, and Jennifer Clement, "The Art of Feeling in Seventeenth-Century English Sermons," English Studies 98, no.7 (2017): 675-88.

9 Barbara Rosenwein, Emotional Communities in the Early Middle Ages (Ithaca: Cornell University Press, 2006). For a discussion of Rosenwein's concept and its impact on the field of the history of emotions, see Jan Plamper, The History of Emotions: An Introduction (Cambridge: Cambridge University Press, 2015), 67-74.

10 Karant-Nunn, Reformation of Feeling, 16-60; Thomas Worcester, Jr., "The Catholic Sermon," in Preachers and People in the Reformations and Early Modern Period, ed. Larissa Taylor (Leiden: Brill, 2011), 3-34.

11 Karant-Nunn, Reformation of Feeling, 65-82.

12 Karant-Nunn, Reformation of Feeling, 101-4. For an exhaustive analysis of Calvin's preaching style, see Olivier Millet, Calvin et la dynamique du parole: Étude du rhétorique réformée (Geneva: Éditions Slatkine, 1992).

13 Jean Calvin, Plusieurs sermons de Jehan Calvin touchant la divinité, humanité et nativité de nostre Seigneur Jesus Christ (Geneva, 1558), 130.

14 Van der Linden, Experiencing Exile, 62-69; Van der Linden, "Preaching in Print: Huguenot Sermons in the Dutch Republic, 1685-1700," Diasporas 18 (2011): 62-77; Hans Bots, "Les pasteurs français au Refuge dans les Provinces-Unies: Un groupe socio-professionnel tout particulier, 1680-1710," in La Vie intellectuelle aux Refuges protestants: Actes de la Table ronde de Münster du 25 juillet 1995, ed. Jens Häseler and Antony McKenna (Paris: Honoré Champion, 1999), 9-10.

15 John Calvin, Institutes of the Christian Religion, trans. John T. McNeill (Louisville, KY: Westminster John Knox Press, 2006), 197-98.

16 Consistory Minutes Walloon Church Delft, 19 August 1686, Archives of the Walloon Church 143, fol. 50, Gemeentearchief, Delft.

17 Jean Claude, Recueil de sermons sur divers textes de l'Ecriture sainte, prononcez par Jean Claude, Ministre dans l'Eglise Réformée de Paris (Geneva, 1693), 519. Claude's life and career are outlined in Abel Rotolp de la Devèze, Abregé de la vie de Mr. Claude (Amsterdam, 1687).

18 Claude, Recueil de sermons, 500-3, 518-22.

19 Calvin, Institutes of the Christian Religion, 200, 218-21.

20 On Abbadie's career, see Ruth Whelan, "Between Two Worlds: The Political Theory of Jacques Abbadie (1656-1727)," Lias 14, no.1 (1987): 101-17, and 14, no.2 (1987): 143-56.

21 Jacques Abbadie, Les caracteres $d u$ Chrestien et $d u$ Christianisme (The Hague, 1686), 147.

22 Abbadie, Les caracteres du Chrestien, 154.

23 Claude, Recueil de sermons, 521. 
24 Abel Rotolp de la Devèze, Sermons sur divers textes de l'Ecriture Sainte, prononcez à La Haye (Utrecht, 1690), 88.

25 Whelan, "Between Two Worlds," 105-7.

26 Jacques Abbadie, L'esprit du christianisme, ou l'excellence de la charité (London, 1694), 25.

27 Rosenwein, Emotional Communities, 25.

28 For the themes discussed in pastoral letters, see Laetitia Cherdon, "La dénonciation du nicodémisme à l'époque de la Révocation de l'Edit de Nantes," Bulletin de la Société de l'Histoire du Protestantimse Français 153, no.1 (2007): 47-65; Chrystel Bernat, "Chute et défaillance: Dénoncer l'infidélité à l'égard de la foi: Altérités intraprotestantes autour de la Révocation," in Enoncer/dénoncer l'autre: Discours et représentations du différend confessionnel à l'époque moderne, ed. Chrystel Bernat and Hubert Bost (Turnhout: Brepols, 2012), 127-46.

29 Van der Linden, Experiencing Exile, 121.

30 De la Devèze, Sermons sur divers textes, preface, sig. *2.

31 Jean Guillebert, Sermons sur divers textes de l'Ecriture Sainte (Amsterdam, 1687). His career is outlined in Sophronyme Beaujour, Essai sur l'histoire de l'église réformée de Caen (Caen, 1877), 335-36; Luc Daireaux, Réduire les Huguenots: Protestants et pouvoirs en Normandie au XVIIe siècle (Paris: Honoré Champion, 2010), 556-62.

32 Jean Guillebert, "Le malheur des Apostats," in Sermons sur divers textes, 54.

33 Jacques Bernard, Traité de la repentance tardive (Amsterdam, 1712), 14-17.

34 Bernard, Traité de la repentance, 78.

35 Pierre Du Bosc, Les larmes de Saint Pierre, ou Sermon sur ces paroles de l'Evangile selon S. Luc, ch. 22 v. 62, Alors Pierre estant sorty dehors, pleura amerement (Geneva, 1660).

36 Samuel de Brais, Le tableau de la repentance (Rotterdam, 1693), 58.

37 Guillebert, Le malheur des Apostats, 32-33.

38 Peter N. Stearns and Carol Z. Stearns, "Emotionology: Clarifying the History of Emotions and Emotional Standards," The American Historical Review 90, no.4 (1985): 813-36.

39 Karant-Nunn, Reformation of Feeling, 7-8. For the training of Huguenot ministers, see Karin Maag, "The Huguenot Academies: Preparing for an Uncertain Future," in Society and Culture in the Huguenot World, 1559-1685, ed. Raymond A. Mentzer and Andrew Spicer (Cambridge: Cambridge University Press, 2002), 139-56.

40 Michel le Faucheur, Traitté de l'action de l'orateur, ou de la prononciation et du geste (Paris, 1675), 3-4. On Le Faucheur's manual, see Cinthia Meli, "Le prédicateur et ses doubles: Actio oratoire et jeux scéniques dans le Traité de l'action de l'orateur de Michel de Faucheur," in Le temps des beaux sermons, ed. Jean-Pierre Landry (Lyon: Centre Jean Prévost, 2006), 117-38.

41 Jean Claude, "Traité de la composition d'un sermon," in Les exuvres posthumes de Mr. Claude, ed. Isaac Claude (Amsterdam, 1688), 1:161-492.

42 Jacques Colas de la Treille, Sermons sur divers textes de l'Ecriture Sainte (Amsterdam, 1727), 1:xiii-xiv.

43 For Bernard's career in exile, see Marion Brétéché, Les compagnons de Mercure: Journalisme et politique dans l'Europe de Louis XIV (Ceyzérieux: Champ Vallon, 2015), 79-80.

44 "Remarques faites aux Leçons de Mr. Bernard sur l'art de bien prêcher," ca. 1706, BWA MB 26, fol. 209, Bibliothèque Wallonne, University Library, Leiden.

45 Pierre Du Bosc, Sermons sur divers Textes de l'Ecriture Sainte (Rotterdam, 1687) 226-32.

46 Bernard, Traité de la repentance tardive, 104-6.

47 Keith P. Luria, Sacred Boundaries: Religious Coexistence and Conflict in Early Modern France (Washington: The Catholic University of America Press, 2005), 85-99; Bernard Dompnier, "Le missionnaire et son public: Contribution à l'étude de la prédication populaire," in La prédication au XVIIe siècle, ed. Thérèse Goyet and Jean-Pierre Collinet (Paris: Nizet, 1980), 105-28. On Catholic missions in general, see Louis Châtellier, The Religion of the Poor: Rural Missions in Europe and the 
Formation of Modern Catholicism, c.1500-c.1800 (Cambridge: Cambridge University Press, 1997).

48 For Isaac's life and career, see David van der Linden, "Predikanten in ballingschap: De carrièrekansen van Jean en Isaac Claude in de Republiek," De Zeventiende Eeuw 27, no.2 (2011): 153-56.

49 Mémoires inédits et opuscules de Jean Rou, ed. Francis Waddington (Paris, 1857), 1:311.

50 Isaac Claude, "Sermon on Romans 8:18, The Hague, 29 August 1685," BWA MC 7, fol. 1, Bibliothèque Wallonne, University Library, Leiden.

51 Rosenwein, Emotional Communities, 23-24.

52 Jeroen Blaak, Literacy in Everyday Life: Reading and Writing in Early Modern Dutch Diaries (Leiden: Brill, 2009), 113-87.

53 Pieter Teding van Berkhout, "Journal de mes occupations," 29 February 1688, MS 129 D 16, Koninklijke Bibliotheek, The Hague.

54 Walter C. Utt and Brian E. Strayer, The Bellicose Dove: Claude Brousson and Protestant Resistance to Louis XIV, 1647-1698 (Brighton: Sussex Academic Press, 2003); Léopold Nègre, Vie et ministère de Claude Brousson, 1647-1698, d'après des documents pour la plupart inédits (Paris, 1878).

55 Lettres et opuscules de feu Monsr. Brousson, Ministre \& Martyr du St. Evangile (Utrecht, 1701), 1-54. For the debate on the departure of Huguenot ministers: Van der Linden, Experiencing Exile, 121-24.

56 Brousson to Couët du Vivier, "near Nîmes," 2 March 1698, DB-0367, Brienne Collection, Museum voor Communicatie, The Hague.

\section{Bibliography}

Abbadie, Jacques. Les caracteres du Chrestien et du Christianisme. The Hague, 1686.

Abbadie, Jacques. L'esprit du christianisme, ou l'excellence de la charité. London, 1694.

Beaujour, Sophronyme. Essai sur l'histoire de l'église réformée de Caen. Caen, 1877.

Bernard, Jacques. Traité de la repentance tardive. Amsterdam, 1712.

Bernat, Chrystel. "Chute et défaillance: Dénoncer l'infidélité à l'égard de la foi: Altérités intra-protestantes autour de la Révocation." In Enoncer/dénoncer l'autre: Discours et représentations du différend confessionnel à l'époque moderne, edited by Chrystel Bernat and Hubert Bost, 127-46. Turnhout: Brepols, 2012.

Blaak, Jeroen. Literacy in Everyday Life: Reading and Writing in Early Modern Dutch Diaries. Leiden: Brill, 2009.

Bots, Hans. "Les pasteurs français au Refuge dans les Provinces-Unies: Un groupe socioprofessionnel tout particulier, 1680-1710." In La Vie intellectuelle aux Refuges protestants: Actes de la Table ronde de Münster du 25 juillet 1995, edited by Jens Häseler and Antony McKenna, 9-18. Paris: Honoré Champion, 1999.

Brétéché, Marion. Les compagnons de Mercure: Journalisme et politique dans l'Europe de Louis XIV. Ceyzérieux: Champ Vallon, 2015.

Calvin, Jean. Plusieurs sermons de Jehan Calvin touchant la divinité, humanité et nativité de nostre Seigneur Jesus Christ. Geneva, 1558.

Calvin, John. Institutes of the Christian Religion. Translated by John T. McNeill. Louisville, KY: Westminster John Knox Press, 2006.

Châtellier, Louis. The Religion of the Poor: Rural Missions in Europe and the Formation of Modern Catholicism, c.1500-c.1800. Cambridge: Cambridge University Press, 1997.

Cherdon, Laetitia. "La dénonciation du nicodémisme à l'époque de la Révocation de l'Edit de Nantes." Bulletin de la Société de l'Histoire du Protestantisme Français 153, no.1 (2007): 47-65. 
Claude, Jean. "Traité de la composition d'un sermon." In Les auvres posthumes de Mr. Claude, edited by Isaac Claude, 1: 161-492. Amsterdam, 1688.

Claude, Jean. Recueil de sermons sur divers textes de l'Ecriture sainte, prononcez par Jean Claude, Ministre dans l'Eglise Réformée de Paris. Geneva, 1693.

Clement, Jennifer. "The Art of Feeling in Seventeenth-Century English Sermons." English Studies 98, no.7 (2017): 675-88.

Colas de la Treille, Jacques. Sermons sur divers textes de l'Ecriture Sainte. Amsterdam, 1727.

Daireaux, Luc. Réduire les Huguenots: Protestants et pouvoirs en Normandie au XVIIe siècle. Paris: Honoré Champion, 2010.

De Brais, Samuel. Le tableau de la repentance. Rotterdam, 1693.

Dompnier, Bernard. "Le missionnaire et son public: Contribution à l'étude de la prédication populaire." In La prédication au XVIIe siècle, edited by Thérèse Goyet and JeanPierre Collinet, 105-28. Paris: Nizet, 1980.

Du Bosc, Pierre. Les larmes de Saint Pierre, ou Sermon sur ces paroles de l'Evangile selon S. Luc, ch. 22 v. 62, Alors Pierre estant sorty dehors, pleura amerement. Geneva, 1660.

Du Bosc, Pierre. Sermons sur divers Textes de l'Ecriture Sainte. Rotterdam, 1687.

Guillebert, Jean. Sermons sur divers Textes de l'Ecriture Sainte. Amsterdam, 1687.

Hunt, Arnold. The Art of Hearing: English Preachers and Their Audiences, 1590-1640. Cambridge: Cambridge University Press, 2010.

Karant-Nunn, Susan. The Reformation of Feeling: Shaping the Religious Emotions in Early Modern Germany. Oxford: Oxford University Press, 2010.

Le Faucheur, Michel. Traitté de l'action de l'orateur, ou de la prononciation et du geste. Paris, 1675.

Lettres et opuscules de feu Monsr. Brousson, Ministre \& Martyr du St. Evangile. Utrecht, 1701.

Luria, Keith P. Sacred Boundaries: Religious Coexistence and Conflict in Early Modern France. Washington: The Catholic University of America Press, 2005.

Maag, Karin. "The Huguenot Academies: Preparing for an Uncertain Future." In Society and Culture in the Huguenot World, 1559-1685, edited by Raymond A. Mentzer and Andrew Spicer, 139-56. Cambridge: Cambridge University Press, 2002.

McCullough, Peter, Hugh Adlington, and Emma Rhatigan, eds. The Oxford Handbook of the Early Modern Sermon. Oxford: Oxford University Press, 2011.

Meli, Cinthia. "Le prédicateur et ses doubles: Actio oratoire et jeux scéniques dans le Traité de l'action de l'orateur de Michel de Faucheur." In Le temps des beaux sermons, edited by Jean-Pierre Landry, 117-38. Lyon: Centre Jean Prévost, 2006.

Millet, Olivier. Calvin et la dynamique du parole: Étude du rhétorique réformée. Geneva: Éditions Slatkine, 1992.

Morrissey, Mary. "Exhortation and Sympathy in the Paul's Cross Jeremiads." English Studies 98, no.7 (2017): 661-74.

Nègre, Léopold. Vie et ministère de Claude Brousson, 1647-1698, d'après des documents pour la plupart inédits. Paris, 1878.

Pineton de Chambrun, Jacques. Les larmes de Jacques Pineton de Chambrun, Pasteur de la Maison de Son Altesse Serenissime, de l'Eglise d'Orange, \& Professeur en Theologie. The Hague, 1687.

Plamper, Jan. The History of Emotions: An Introduction. Cambridge: Cambridge University Press, 2015.

Rosenwein, Barbara H. Emotional Communities in the Early Middle Ages. Ithaca: Cornell University Press, 2006.

Rotolp de la Devèze, Abel. Abregé de la vie de Mr. Claude. Amsterdam, 1687. 


\section{David van der Linden}

Rotolp de la Devèze, Abel. Sermons sur divers textes de l'Ecriture Sainte, prononcez à La Haye. Utrecht, 1690.

Stearns, Peter N., and Carol Z. Stearns. "Emotionology: Clarifying the History of Emotions and Emotional Standards." The American Historical Review 90, no.4 (1985): 813-36.

Todd, Margo. The Culture of Protestantism in Early Modern Scotland. New Haven: Yale University Press, 2002.

Utt, Walter C., and Brian E. Strayer. The Bellicose Dove: Claude Brousson and Protestant Resistance to Louis XIV, 1647-1698. Brighton: Sussex Academic Press, 2003.

Van der Linden, David. "Preaching in Print: Huguenot Sermons in the Dutch Republic, 1685-1700.” Diasporas 18 (2011): 62-77.

Van der Linden, David. "Predikanten in ballingschap: De carrièrekansen van Jean en Isaac Claude in de Republiek." De Zeventiende Eeuw 27, no.2 (2011): 153-56.

Van der Linden, David. Experiencing Exile: Huguenot Refugees in the Dutch Republic, 1680-1700. Farnham: Ashgate, 2015.

Francis Waddington, ed. Mémoires inédits et opuscules de Jean Rou. Paris, 1857.

Whelan, Ruth. "Between Two Worlds: The Political Theory of Jacques Abbadie (1656-1727)." Lias 14, no.1 (1987): 101-17, and 14, no.2 (1987): 143-56.

Worcester, Thomas Jr. "The Catholic Sermon." In Preachers and People in the Reformations and Early Modern Period, edited by Larissa Taylor, 3-34. Leiden: Brill, 2011. 